\title{
Giant insulinoma: an unusual cause of hypoglycaemia
}

Essam Lakha, ${ }^{1}$ Ermanno Capuano, ${ }^{2}$ Imran Syed, ${ }^{3}$ Emily Norman ${ }^{4}$

Foundation Training, Basildon and Thurrock University

Hospitals NHS Foundation Trust, Basildon, UK

${ }^{2}$ Radiology, Basildon and

Thurrock University Hospital NHS Foundation Trust, Basildon,

UK

${ }^{3}$ Radiology, Basildon and Thurrock University Hospital NHS Foundation Trust, Basildon, UK

${ }^{4}$ Foundation Training,

Whittington Hospital, London, UK

Correspondence to Dr Essam Lakha,

essam.lakha@hotmail.co.uk

Accepted 3 October 2017

\section{DESCRIPTION}

A 70-year-old non-diabetic man presented to the accident and emergency department with convulsions and symptoms of hunger, anxiety and blurred vision. A non-tender epigastric mass was identified,

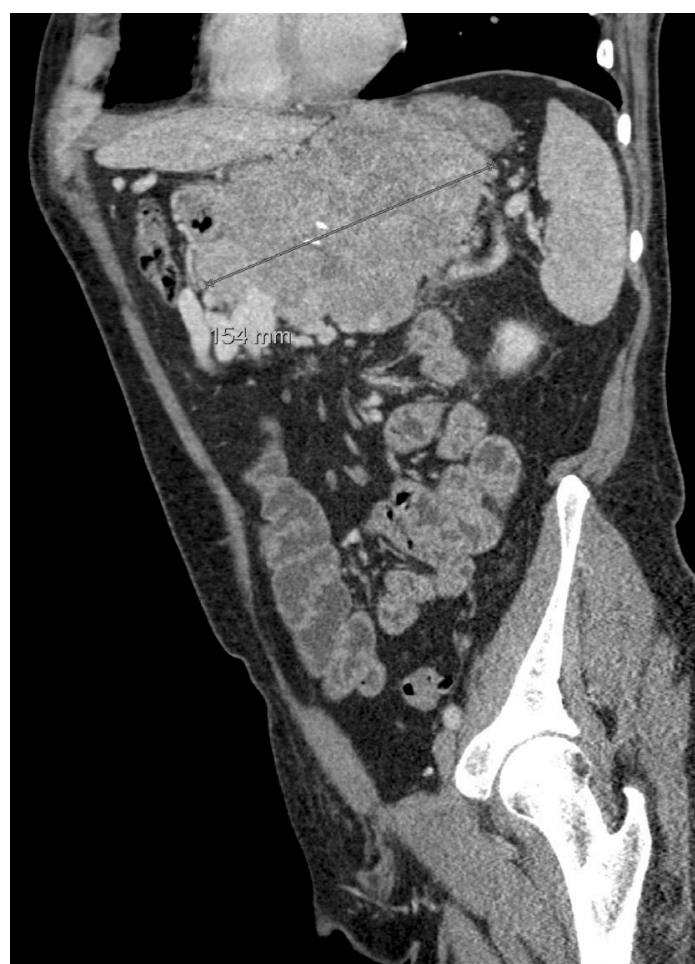

Figure 1 Multiplanar reconstruction identifying the $154 \mathrm{~mm}$ insulinoma.

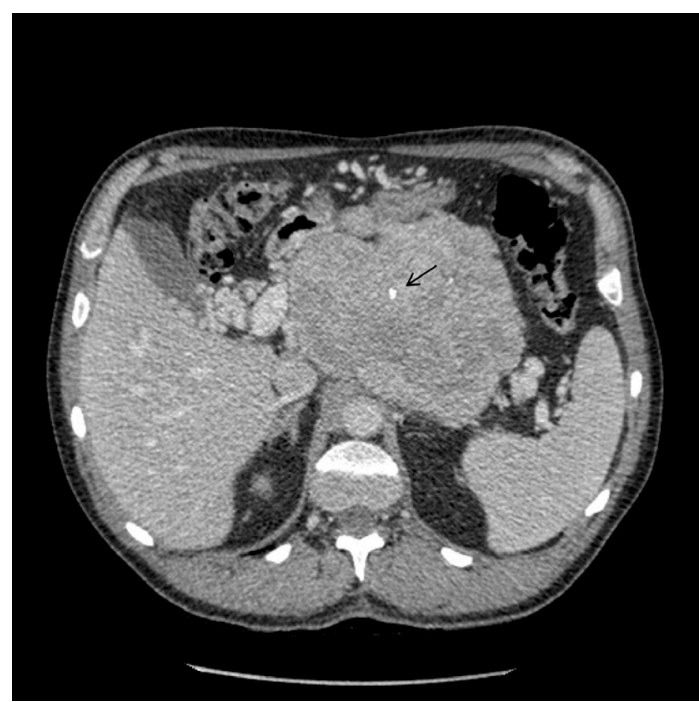

Figure 2 Axial image revealing calcifications typical of insulinomas (black arrow).

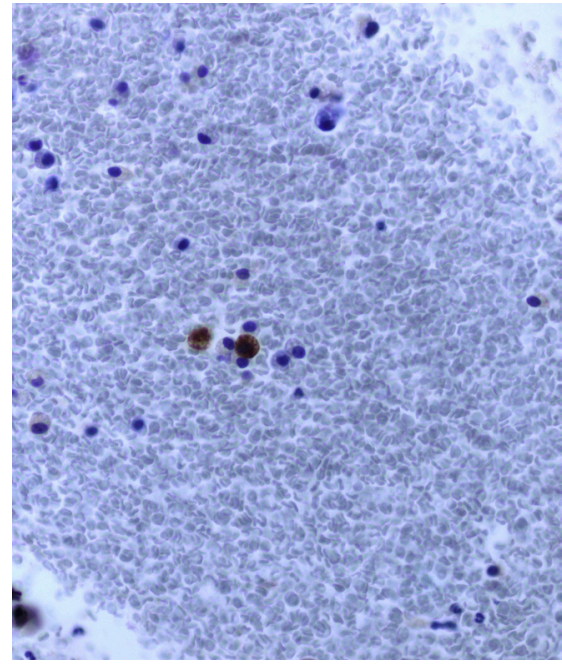

Figure 3 Immunostained section for insulin showing positivity in a few neuroendocrine tumour cells.

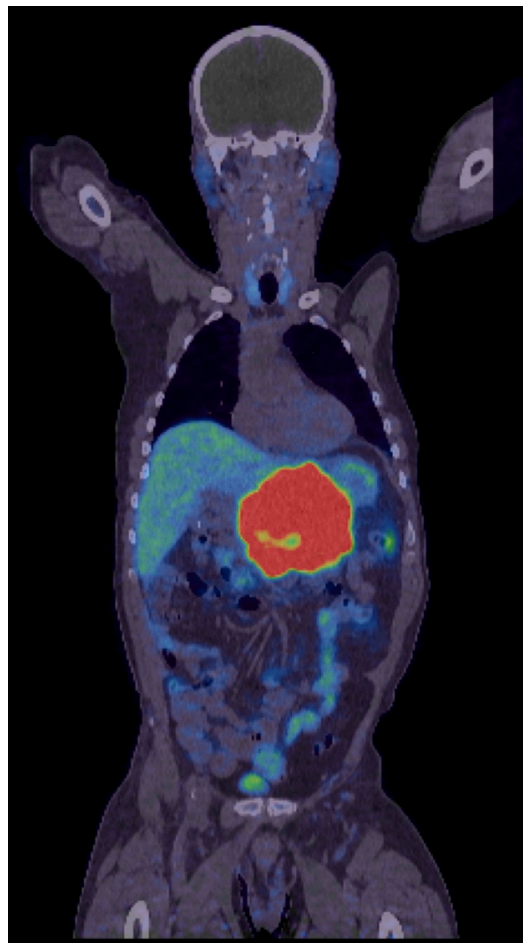

Figure 4 Coronal fused image demonstrating 68-GaDOTATATE avid pancreatic tumour. Physiological uptake can be seen within the adrenal glands, spleen and kidneys.

and he was found to be hypoglycaemic, with plasma glucose levels of $1.5 \mathrm{mmol} / \mathrm{L} \quad(4.4-6.1 \mathrm{mmol} / \mathrm{L})$. C-peptide and insulin levels were both inappropriately elevated. 


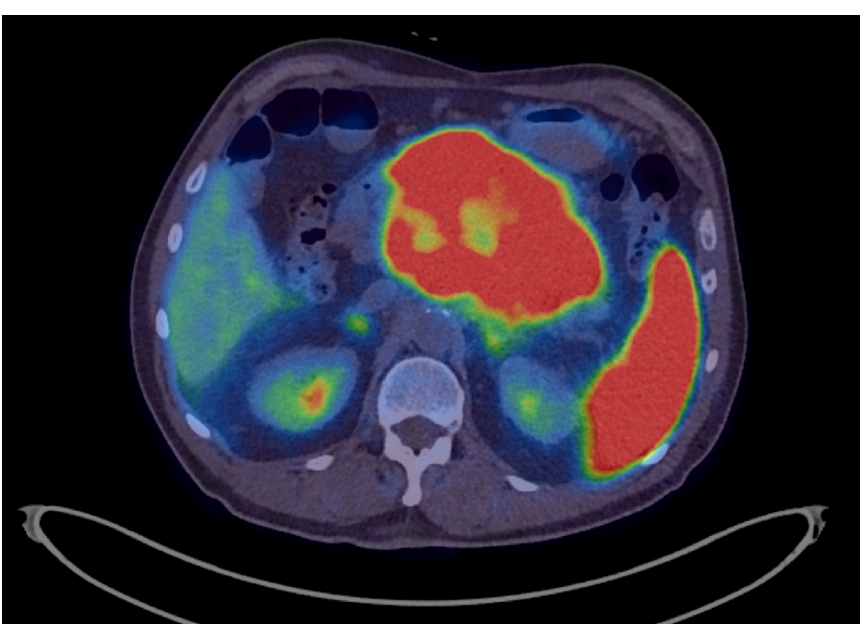

Figure 5 Axial fused image from positron emission tomography 68-Ga-DOTATATE study.

After stabilisation with glucose, the patient was investigated with CT, which revealed a $154 \mathrm{~mm}$ mass in the pancreas that displaced the stomach and encased the coeliac trunk, the superior mesenteric vein and the splenic vein (figure 1). Collaterals were found at the level of the hepatic hilum, the gastro-oesophageal junction and adjacent to the mass itself. Calcifications typical of insulinomas were evident (figure 2). No metastases were seen. Fine-needle aspiration was then performed, confirming the diagnosis (figure 3 ).

Treatment consisted of diazoxide to control hypoglycaemia and a chemotherapy regime that included streptozocin. Following this, positron emission tomography 68-Ga-DOTATATE scanning allowed staging of the tumour and confirmed the absence of metastases (figures 4 and 5). It was determined that the mass was still too large to be surgically resected. Nonetheless, the patient remains asymptomatic.

Although rare, insulinoma should be considered as a differential diagnosis in the non-diabetic presenting with hypoglycaemia. Insulinomas arise from the ductal/acinar system of the pancreas. ${ }^{1}$ Only $5 \%$ of reported cases are larger than $3 \mathrm{~cm}^{2}$

\section{Learning points}

- Patients with insulinoma usually present with hypoglycaemia and are found to have a low plasma glucose at the time of their symptoms. These symptoms resolve with glucose. This is known as Whipple's triad.

- Insulinomas are usually small in size and benign in nature. They are thus usually treated with curative resection after adequate localisation with imaging.

- Giant insulinomas are more likely to display malignant characteristics and are less amenable to surgery. In these cases, hypoglycaemic symptoms can be managed with diazoxide.

Surgical resection remains the optimal treatment for insulinomas and is usually performed with curative intent. The prognosis for smaller insulinomas is excellent. However, giant insulinomas are more likely to behave malignantly and are less amenable to curative surgery. ${ }^{3}$

Contributors EL and EN carried out the initial literature review and wrote the bulk of the text under the guidance of radiologists EC and IS. IS and EC reported and provided the images for the report. They acted as project leads and supervisors for $\mathrm{EL}$ and EN when writing the manuscript. Numerous revisions were made by them prior to submission. All four authors contributed to the end result of this report and are all happy with the final product.

Competing interests None declared.

Patient consent Obtained.

Provenance and peer review Not commissioned; externally peer reviewed.

(C) BMJ Publishing Group Ltd (unless otherwise stated in the text of the article) 2017. All rights reserved. No commercial use is permitted unless otherwise expressly granted.

\section{REFERENCES}

1 Vortmeyer AO, Huang S, Lubensky I, et al. Non-islet origin of pancreatic tumours. J Clin Endocrinol Metab 1934;2004:89.

2 Service FJ, McMahon MM, O'Brien PC, et al. Functioning insulinoma-incidence, recurrence, and long-term survival of patients: a 60-year study. Mayo Clin Proc 1991;66:711-9.

3 Ueda K, Taira T, Hakoda H, et al. Giant insulinoma: report of a case and review of published reports. Surg Case Rep 2016;2:136.

Copyright 2017 BMJ Publishing Group. All rights reserved. For permission to reuse any of this content visit

http://group.bmj.com/group/rights-licensing/permissions.

BMJ Case Report Fellows may re-use this article for personal use and teaching without any further permission.

Become a Fellow of BMJ Case Reports today and you can:

- Submit as many cases as you like

- Enjoy fast sympathetic peer review and rapid publication of accepted articles

- Access all the published articles

- Re-use any of the published material for personal use and teaching without further permission

For information on Institutional Fellowships contact consortiasales@bmjgroup.com

Visit casereports.bmj.com for more articles like this and to become a Fellow 